DOI: $10.7242 / 2658-705 X / 2019.3 .1$

УДК 550.831

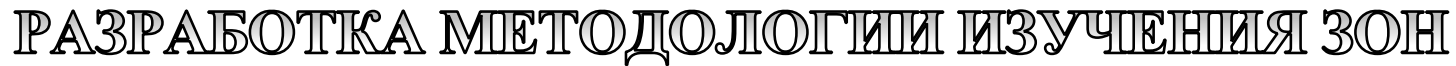

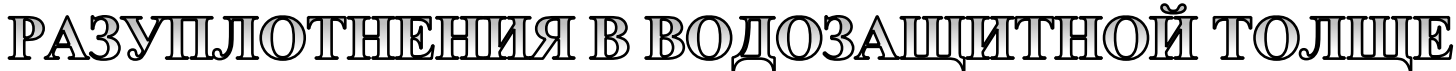

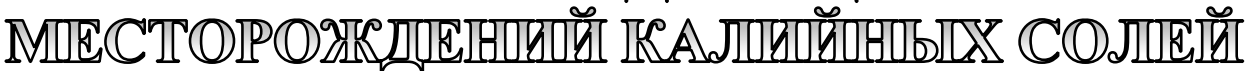

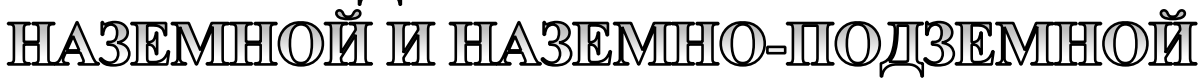

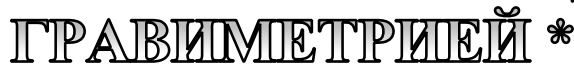

С.Г. Бычков, Горный институт УрО РАН

А.В. Мичурин, Горный институт УрО РАН

Г.В. Простолупов, Горный институт УрО РАН

А.А. Симанов, Горный институт УрО РАН

В.В. Хохлова, Горный институт УрО РАН

При поддержке проекта регионального конкурса РФФИ в 2016-2018 гг. проводились исследования по применению гравиметрии для изучения и прогнозирования негативных инженерно-геологических явлений, вызванных процессом эксплуатации месторождений калийных солей. В процессе выполнения проекта разработаны методики высокоточной наземной, наземно-подземной гравиметрической съемок и мониторинговых наблюдений, выполнена адаптация способов обработки гравиметрических данных этих съемок, созданы компьютерные алгоритмы обработки наблюдений.

Предложены способы интерпретации наземной, наземно-подземной и мониторинговой гравиметрической съемок на основе совместного применения качественных и количественных методов извлечения геологической информации из гравиметрических данных. Применение гравиметрического мониторинга на аварийных участках рудников Верхнекамского месторождения калийных солей показало его высокую эфффективность.

Установлено, что провалы земной поверхности и участки повышенных оседаний, обусловленные затоплением рудников, отчетливо фриксируются в гравитационном поле. По сочетанию отрицательных локальных аномалий силы тяжести, которые интерпретируются как природные ослабленные зоны с отрицательными динамическими аномалиями, связанными с продолжением процесса разуплотнения, можно успешно прогнозировать участки опасных геологических процессов.

Ключевые слова: гравиметрия, соли, чахта, аномалия сильи тяжести, трехмерная модель.

\footnotetext{
* Исследования в данном направлении проводятся при финансовой поддержке регионального конкурса РФФИ проекты № №17-45-590302 p_a «Разработка методики мониторинговых гравиметрических исследований для изучения карстовых процессов» и № 19-45-590011 p_a «Разработка критериев выявления техногенных разуплотненных зон в подработанном массиве по данным высокоточных гравиметрических наблюдений».
} 
Одной из основных задач геофизического сопровождения работ при освоении месторождений полезных ископаемых является обеспечение безопасности и безаварийной разработки месторождений, которое должно включать изучение состояния горного массива до начала разработки и систему контроля геодинамических и техногенных процессов в процессе добычи полезного ископаемого. На Верхнекамском месторождении калийных солей (ВКМКС), расположенном в Соликамской впадине Предуральского прогиба, основная цель проводимых геофизических работ - защита рудников от затопления надсолевыми водами. Гравиметрия включена в комплекс геофизических исследований и решает различные задачи: обнаружение разуплотненных ослабленных участков на подготавливаемых к отработке площадях, выявление таких участков на уже подработанных территориях, мониторинг состояния породного массива на участках со сложным геологическим строением $[11,13]$.

Высокая информативность гравиметрических данных на Верхнекамском месторождении калийных солей достигается путем использования высокоточной гравиметрической и топографо-геодезической аппаратуры. Необходимая детальность обеспечивается проведением высокоточных крупномасштабных съемок масштаба 1:5000 и 1:10 000, а также наблюдениями на двух гипсометрических уровнях: на поверхности земли и в шахтах калийных рудников. Обработка гравиметрических данных производится комплексом программ, включающих современные процедуры редуцирования аномалий силы тяжести, которые позволяют повысить информативность гравиметрических данных [1, 2, 4, 5, 15, 23].

Интерпретация аномалий силы тяжести осуществляется на основе совместного применения качественных и количественных методов извлечения геологической информации из гравиметрических данных. На начальной стадии интерпретации для получения приближенных представлений об изучаемых плотностных неоднородностях производится разделение поля на серию «разноглубинных» компонент методом векторного сканирования, затем выполняется серия решений обратной задачи гравиразведки монтажным методом. Полученная совокупность частных решений обратной задачи преобразуется в сеточное распределение вероятности обнаружения объекта - функцию локализации. Такая методика позволяет на каждом шаге интерпретационного процесса приближаться к искомой модели строения изучаемого объема геологической среды [16-20, 26]. По результатам повторных геофизических съемок определяются временные трансформации модели и оценивается степень опасности состояния водозащитной толщи для эксплуатации месторождений.

\section{Прикладные задачи гравиметрии при обеспечении безопасности отработки месторождения растворимых солей}

Рассмотрим результаты переинтерпретации гравиметрических съемок, проведенных ранее с нефтепоисковыми целями на одном из участков ВКМКС, по уточнению плотностного строения массива горных пород и выявлению природных ослабленных зон в надсоляной толще, представляющих опасность для ведения горных работ.

Территория исследований находится в западной части ВКМКС, в области выклинивания соляной толщи. На площади находится поднятие по кровле соли, которое является одной из вершин регионального соляного вала, сформированного вдоль восточной границы Восточно-Европейской платформы $[24,25]$. Слои надсоляной толщи, представленные глинистыми, алевропесчаными, глинисто-карбонатными отложениями, повторяют морфологию соляной поверхности. Верхняя часть надсоляной толщи на вершине поднятия эродирована, имеет неполный разрез, что говорит о разрыхленном состоянии горных пород.

Морфология гравитационного поля, построенного по гравиметрическим съемкам масштабов 1:25000 и 1:50 000 
(рис. 1), имеет почти равномерное уменьшение значений на восток и формируется несколькими основными источниками. Весомый вклад вносит изменение по площади мощности соляной толщи и глубины залегания ее кровли и подошвы. Основная гравиактивная граница расположена между надсоляной толщей, сложенной породами высокой плотности $\left(2,35-2,47\right.$ г/ $\left.\mathrm{cm}^{3}\right)$, и нижележащей толщей соляных пород, характеризующейся низкой плотностью $\left(1,98-2,17\right.$ г/см $\left.{ }^{3}\right)$. По результатам моделирования, соляной купол создает отрицательную аномалию силы тяжести амплитудой около - 1,8 мГал. В скважине 3, пробуренной в 2 км западнее вершины соляного поднятия, наблюдается повторение разреза надсоляной толщи, что свидетельствует о вскрытии скважиной надвига.

Для выяснения характера проявления надвиговой структуры в гравитационном поле был рассчитан гравитационный эффект от кровли соляной толщи для модели надвига. По результатам решения прямой задачи гравиметрии, увеличение мощности плотных надсоляных пород в районе надвига создает положительную аномалию амплитудой 0,7 мГал. На карте поля силы тяжести (рис. 1) в районе скважины 3 отчетливо видна положительная аномалия линейной формы. Ее длина око- ло 3 км, ширина 700-800 м. Амплитуда и ширина аномалии подобны модельным величинам, поэтому по гравиметрическим данным можно протрассировать надвиг на север и юг от скв. 3 (рис. 2).

Выявление данного надвига, осложняющего надсоляную и верхнюю часть соляной толщи, позволит избежать осложнений при последующих горных работах.

Вторая задача при подготовке территории к разработке - выявление разуплотненных участков, которые должны учитываться при проектировании рудников, решалась путем построения разностных трансформант гравитационного поля, отражающих плотностную неоднородность породных слоев на выбранных глубинах. На трансформантах, рассчитанных для глубин залегания надсоляного и верхней части соляного разреза, наблюдается мозаичная картина положительных и отрицательных локальных аномалий. Отрицательные аномалии указывают положение участков разуплотненных пород.

Разуплотненные участки относительно структуры поверхности соляной толщи располагаются закономерно. Например, на трансформанте поля, отражающей плотностное строение надсоляной толщи (см. 2), цепочка локальных аномалий 1 выявлена в области вершины соляного валика, сфор-

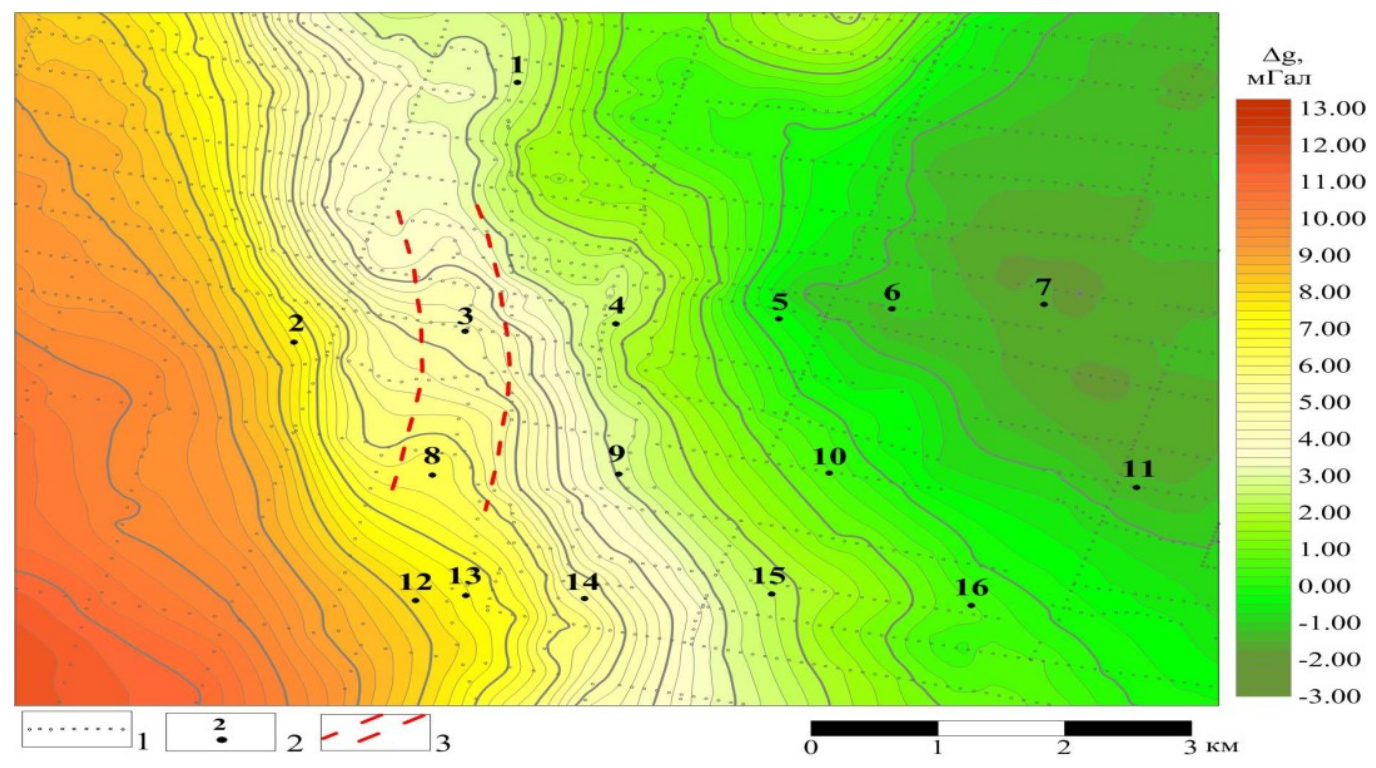

Рис. 1. Гравитациионное поле: 1 - пункты гравиметрических наблюдений, 2 - скважины, 3 - локальная положительная аномалия, обусловленная надвигом 


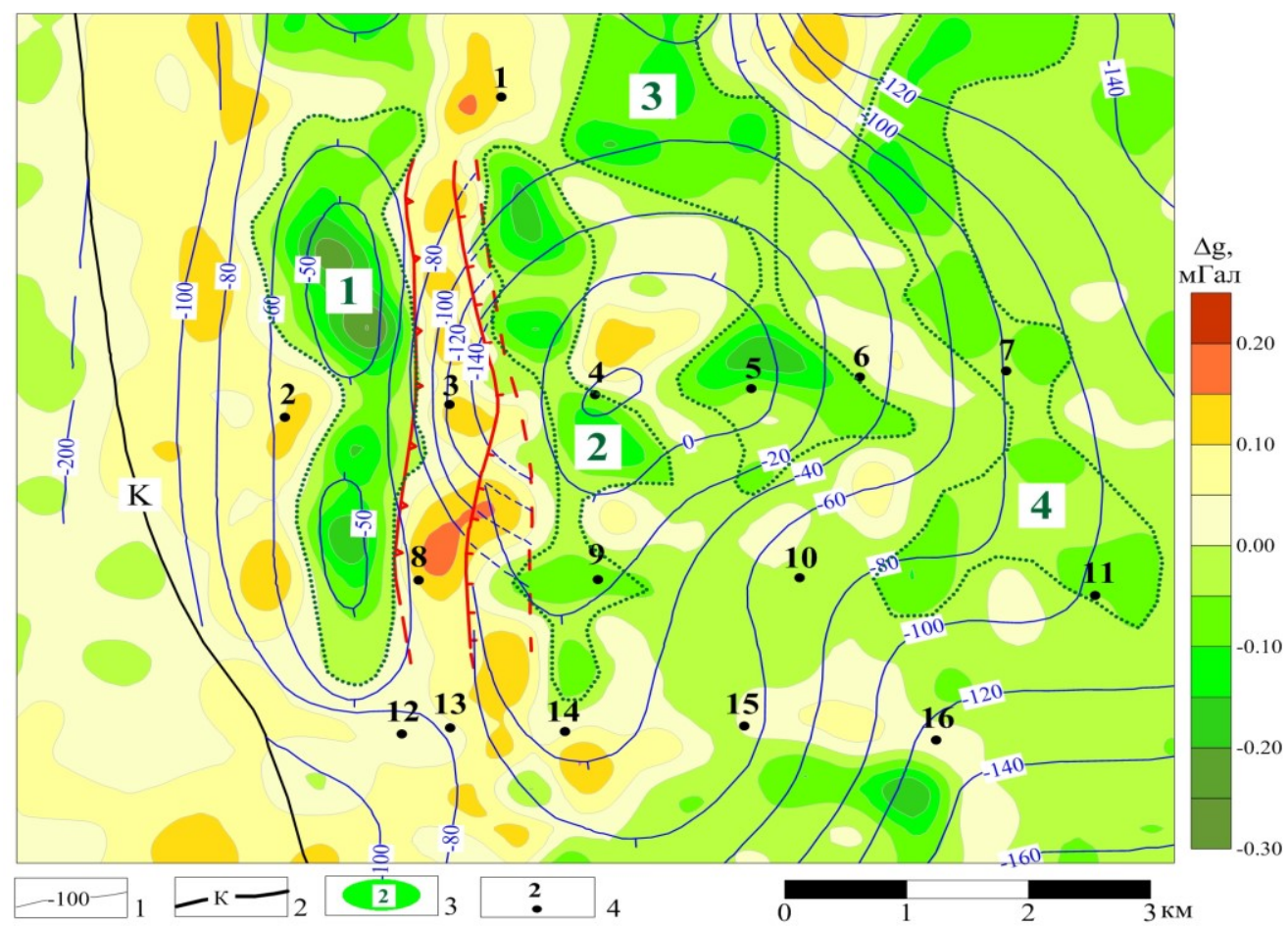

Рис. 2. Плотностное строение надсоляной толщи: 1 - изогипсы кровли солей по скважинным и гравиметрическим данным, 2 - западная граница распространения калийной залежи, 3 - локальные отрицательные аномалии силь тяжести, 4 - скважины

мированного перед фронтом надвига. Серия разуплотнений 2 сформирована в аллохтоне вдоль дизъюнктивного нарушения. Аномалия 3 вытянута вдоль соляного носа в юго-восточном направлении. Аномалии 4 приурочены к склону соляного купола.

Таким образом, применение гравиметрии при подготовке изучаемого участка для проведения горных работ позволило решить две задачи. Вопервых, выяснить положение в плане, выявленного по результатам бурения, надвига, определить его длину. Во-вторых, определить участки с низкими прочностными свойствами пород, т.е. пород пониженной плотности - повышенной пористости и трещиноватости.

\section{Применение наземно-подземной гравиразведки на Верхнекамском месторождении калийных солей}

При производстве наземной съемки глубинная приуроченность источников аномалий и их количественные параметры определяются крайне неустойчиво и неоднозначно. Один из путей преодоления неоднозначности интерпретации - совмест- ный функциональный анализ наблюдений, проведенных на разных гипсометрических уровнях, с решением обратных задач в данной идеологии. Совместная интерпретация разноуровенных наблюдений существенно снижает неоднозначность решения обратной задачи гравиметрии в линейной и нелинейной постановке, повышает разрешающую способность и достоверность выделения плотностных неоднородностей. В связи с этим предлагается подход, заключающийся в проведении и совместном анализе результатов наблюдений, проведенных на нескольких уровнях - наземно-подземная гравиразведка [12, 14].

Добыча полезного ископаемого на рудниках Верхнекамского месторождения калийных солей (ВКМКС) панельная и ведется на глубинах от 250 до 400 м в зависимости от положения продуктивного слоя (карналлит и сильвинит). Выработки представляют собой регулярную сеть, в сечении имеют почти правильную цилиндрическую форму. Это способствует проведению площадной подземной съемки и облегчает процесс введения поправок за выработанное пространство. 
Рассмотрим результаты интерпретации наземно-подземной гравиметрической съемки, проведенной на юго-востоке Четвертого Березниковского рудника, где выполнена площадная съемка в масштабе 1:10 000 на поверхности в объеме 4 км $^{2}$ и в горных выработках на семи профилях на площади около 1 км² (рис. 3). Регистрация значений поля проведена высокоточными гравиметрами Autograv CG-5. Среднеквадратическая погрешность съемки $\pm 0,020$ мГал. Значение гравитационного поля было передано с наземного уровня на подземный. Увязка гравитационного поля на нескольких уровнях предоставляет ряд возможностей, в том числе для расчета средней плотности пород между уровнями наблюдений.

Для локализации источников аномалий в пространстве между двумя уровнями съемки проведено послойное векторное сканирование данных наземного и подземного полей: наземного поля - в нижнее полупространство, подземного в верхнее полупространство. В результате построены две серии трансформант, характеризующих гравитационный эффект от толщи пород, расположенной между двумя уровнями наблюдений. При визуальном анализе трансформант наземного и подземного полей с соответствующими эффективными глубинами было отмечено совпадение в плане наземной отрицательной аномалии и обширной положительной аномалии подземного поля (рис. 4), что свидетельствует о наличии природной зоны разуплотнения, находящейся между двумя уровням съемки, т.е. в водозащитной толще.

Данные наземно-подземной съемки позволили дать исчерпывающую картину распределения аномалий во всем диапазоне водозащитной толщи. В частности, за счет «подземной» диаграммы уточнено положение сквозной разуплотненной зоны, простирающейся от терригенно-карбонатной толщи до кровли продуктивной толщи. Выявленные разуплотнения являются объектами повышенного внимания со стороны геологических служб рудника.

На сегодняшний момент наземно-подземная гравиразведка выполнена почти на всех рудниках Верхнекамского месторождения, однако площадь съемок, проведенных в шахтах, несопоставима с площадью участков выработанного пространства, составляя от последних не более $5 \%$. В целом это говорит о недостаточном использовании мощного средства изучения геологического строения место-
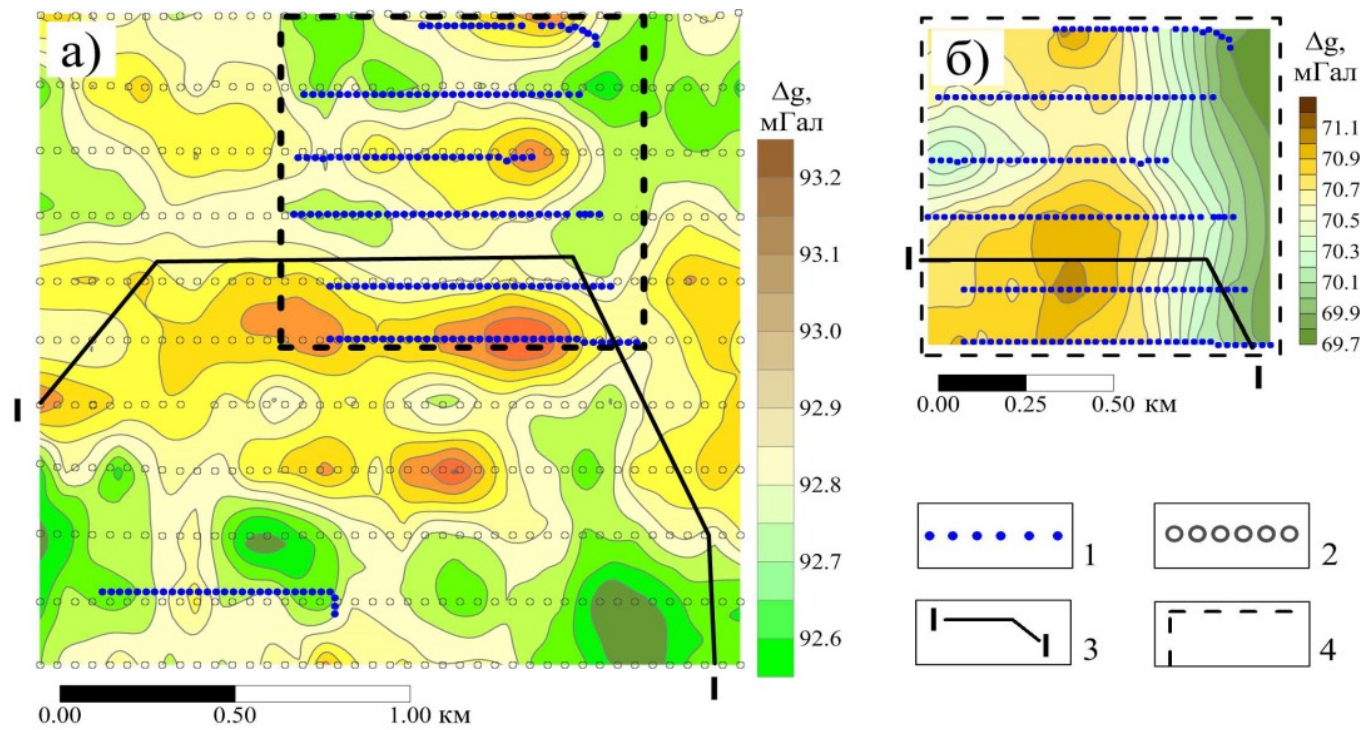

Рис. 3. Наземное (а) и подземное (б) гравитационные поля: 1 - пункты подземной съемки;

2 - пункты наземной съемки; 3 - линии сечений 3D-диаграмм гравитационного поля; 4 - граница обработки данных подземной съемки 


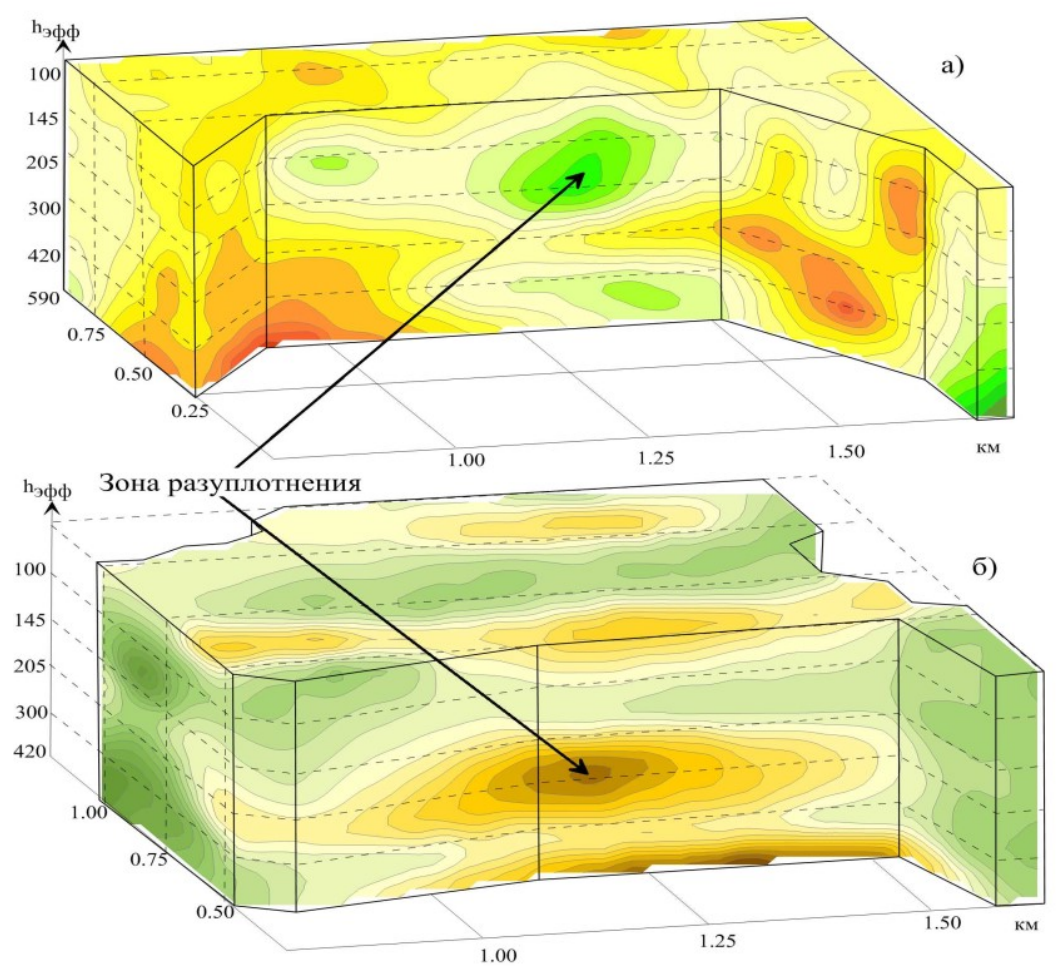

Рис. 4. Вертикальные разрезы 3D диаграмм наземного (а)

и подземного (б) гравитационных полей (положение сечений показано на рис. 3)

рождения и еще не полностью раскрытом потенциале данного метода в обеспечении безаварийной работы рудников.

\section{Гравиметрический мониторинг рудников Верхн екамского месторождения калийных солей}

Мониторинговые наблюдения поля силы тяжести выявляют динамику процессов деформации породных масс и позволяют осуществить прогноз опасных и катастрофических ситуаций. По результатам повторных наблюдений рассчитывается динамическая аномалия силы тяжести, определяемая как разность между последующими и предыдущими значениями силы тяжести. Особенностью подобных аномалий является их независимость от влияния рельефа земной поверхности, стационарных (неизменных) плотностных неоднородностей в массиве, обусловленных геологическим строением. Поскольку все неизменные составляющие гравитационного поля в равной степени присутствуют в любой паре наблюдений, динамическая аномалия отражает только конкретный горнотехнический или быст- ротекущий геологический процесс, такой, как, например, образование и развитие карстовых полостей [6-9, 21, 22, 28].

Геологическая модель гравиметрического мониторинга представляет собой изолированную область, где произошли изменения плотности пород, в однородной геологической среде. Учитывая, что современная гравиметрическая и геодезическая аппаратура позволяет зафиксировать аномалии силы тяжести с точностью $\pm 0.005-$ 0.007 мГал, по гравиметрическим данным можно определить начало процесса разуплотнения пород, выявляя зоны последующих возможных оседаний и провалов земной поверхности [3].

Основываясь на геологической модели гравиметрического мониторинга, разработана методика интерпретации динамических аномалий силы тяжести. На начальной стадии интерпретационного процесса используется система VECTOR, с помощью которой строится изображение геологической среды - пространственное распределение поля, отражающее некоторые элементы физико-гео- 
логической модели. Результаты векторного сканирования успешно используются для уточнения геологических гипотез и задания априорных ограничений при последующем решении обратной задачи.

Решение обратных задач предлагается осуществлять монтажным методом с использованием гарантированного подхода к оценке качества решения обратной задачи и с построением функции локализации источников поля. Модель среды, используемая при этом методе решения задачи (изолированный объект в однородной среде), полностью удовлетворяет геологической модели гравиметрического мониторинга, поскольку влияние неизменных плотностных неоднородностей в массиве, обусловленных геологическим строением, отсутствует в динамических аномалиях силы тяжести. Многократное (до 1500 циклов) решение обратной задачи гравиразведки монтажным методом позволяет получить совокупность частных решений, которые преобразуется в сеточное распределение вероятностных характеристик - функцию локализации $P$, являющееся содержательной геоплотностной моделью. Эта модель обладает реальными пространственными координатами и характеризует распределение аномалиеобразующих масс в изучаемом объеме геологической среды. Области высоких значений $P$ отвечают наиболее достоверно выделяемым возмущающим объектам. Результатом интерпре- тации динамических аномалий является вероятный интервал глубин изменения массы (объема) горных пород, произошедший между двумя парами измерений поля.

Предлагаемый метод интерпретации рассмотрим на примере мониторинговых гравиметрических наблюдений над шахтными полями ВКМКС. В 2006 году проникновение подземных вод в шахты рудника, расположенного под промышленной зоной и жилыми кварталами г. Березники, привело к его затоплению и последующим провалам земной поверхности. В районе провалов проведены детальные мониторинговые гравиметрические съемки с целью оконтуривания и изучения опасных зон, выяснения их природы, глубины распространения разуплотненных пород, а также выявления потенциально опасных участков на прилегающих территориях [10, 27].

На рис. 5 приведено гравитационное поле, измеренное в ноябре 2010 г. после провала земной поверхности, контур которого обозначен цифрой I. На данном участке проведено несколько циклов гравиметрических наблюдений. В феврале 2011 г. съемка была повторно проведена на всей площади, в сентябре 2011 г. в центральной части и в 20162018 гг. - на востоке площади.

Гравиметрические работы выполнялись на закрепленных металлических знаках (дюбелях, забитых в асфальт) грави-

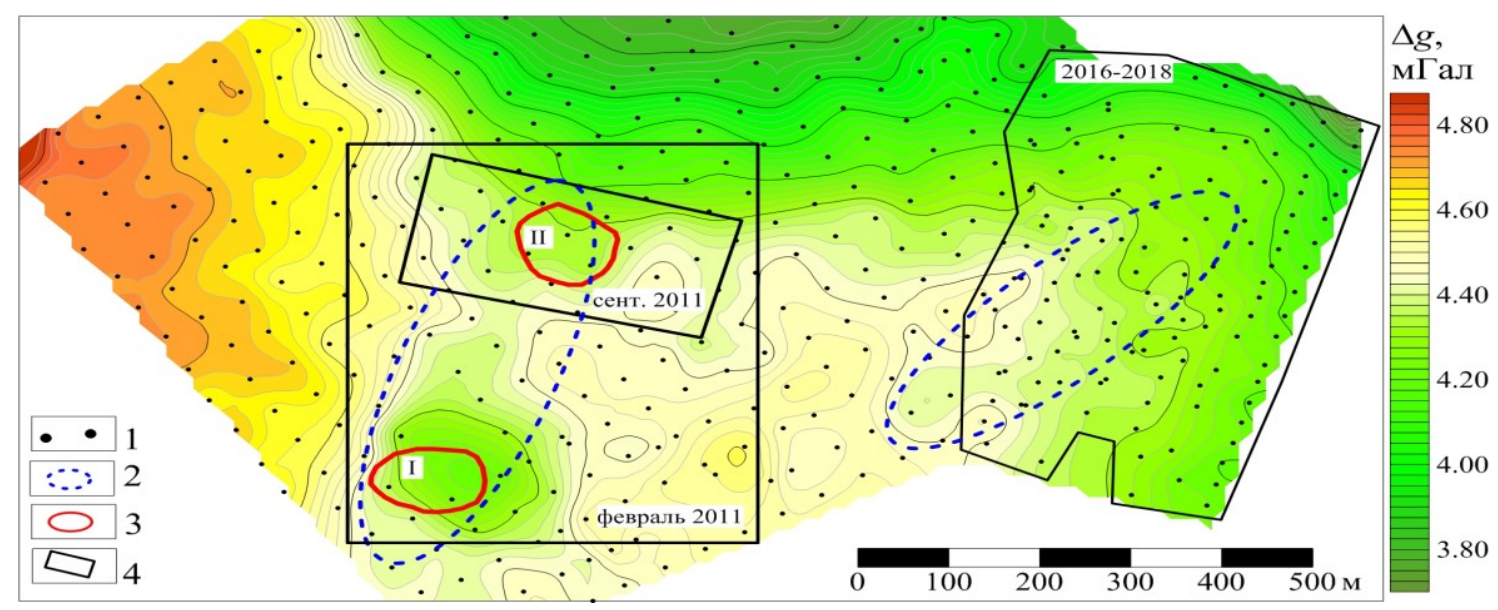

Рис. 5. Гравитациионое поле в редукции Буге в районе провалов земной поверхности:

1 - пункты гравиметрических наблюдений; 2 - локальные отрищательные аномалии силь тяжести; 3 - проваль земной поверхности (I - ноябрь 2010 г. и декабрь 2011 г.),

4 - участки повторной гравиметрической съемки 
метрами AUTOGRAV CG-5 по сети $50 \times 50$ м. Планово-высотная привязка пунктов гравиметрической съемки осуществлена с использованием GNSS-приемника Trimble R-8. Точность определения значений силы тяжести составила $\pm 0,005-$ 0,010 мГал, высот пунктов - $\pm 0,01-0,02 \mathrm{м}$. Данная точность достигалась путем многократных наблюдений на каждом пункте. Наблюдения выполнялись относительно исходного гравиметрического пункта, расположенного в 15 км от города вне зоны влияния инженерно-геологических, горнотехнических и геодинамических процессов. Сравнивались аномалии в редукции Буге, т.е. учитывалось изменение высоты гравиметрических пунктов.

Повторной съемкой в феврале 2011 г. динамические аномалии силы тяжести амплитудой до $-0,15$ мГал были выявлены только вблизи провала I (рис. 6,a). Обращает на себя внимание пространственное совпадение динамической и локальной отрицательной аномалий силы тяжести (рис. 6,б). Данный факт можно интерпретировать как существование природной зоны разуплотненных пород, к которой приурочены техногенные процессы, приводящие к провалам земной поверхности. Результаты интерпретации динамической аномалии в системе VECTOR (рис. 6,6) и построение функции локализации $(P)$ (рис. 6,2) показали, что зона разуплотнения расположена на глубинах $H$ от 50 м до 100 м и приурочена к водозащитной надсоляной толще, разрушение которой привело к образованию провала.

В сентябре 2011 г. в зоне повышенных оседаний земной поверхности к северу от провала вновь проведены гравиметрические измерения, по результатам которых выявлена динамическая аномалия силы тяжести (рис. 7), свидетельствующая о процессе разуплотнения пород, начавшегося после февраля 2011 г. Дальнейшее развитие событий привело к образованию в декабре 2011 г. еще одного провала земной поверхности (обозначенного цифрой II

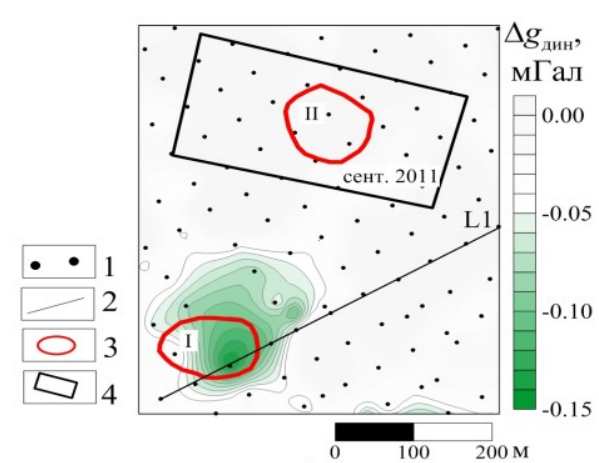

a)

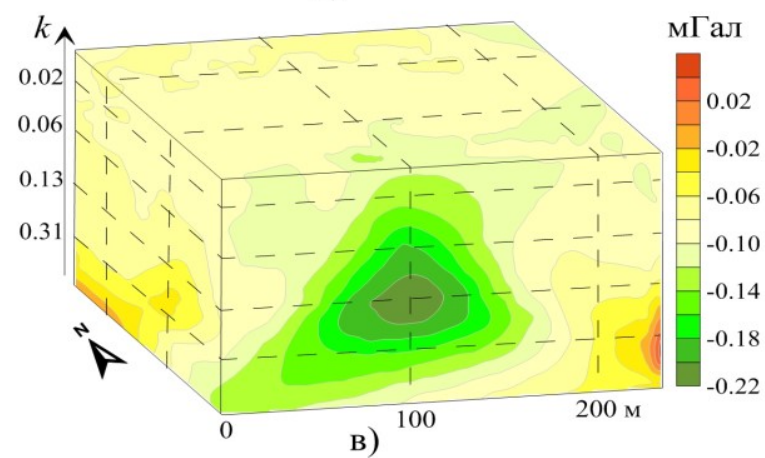

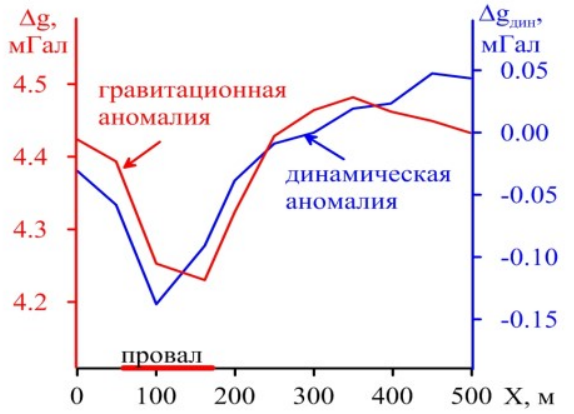

б)

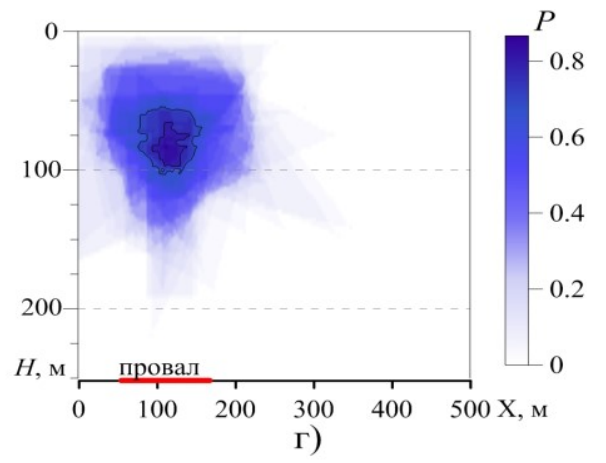

Рис. 6. Результаты интерпретации мониторинговых наблюдений в районе провала I: а) динамические аномалии силь тяжести за период ноябрь 2010 г.- февраль 2011 г.:

1 - пункты гравиметрических наблюдений, 2 -линия профиля L1, 3 - контуры провалов, 4 -участок съемки в сентябре 2011 г.; б) графики аномалий Буге и динамической аномалии nо профилю L1: в) выделение локальной аномалии в системе VECTOR;

г) срез функции локализациии 


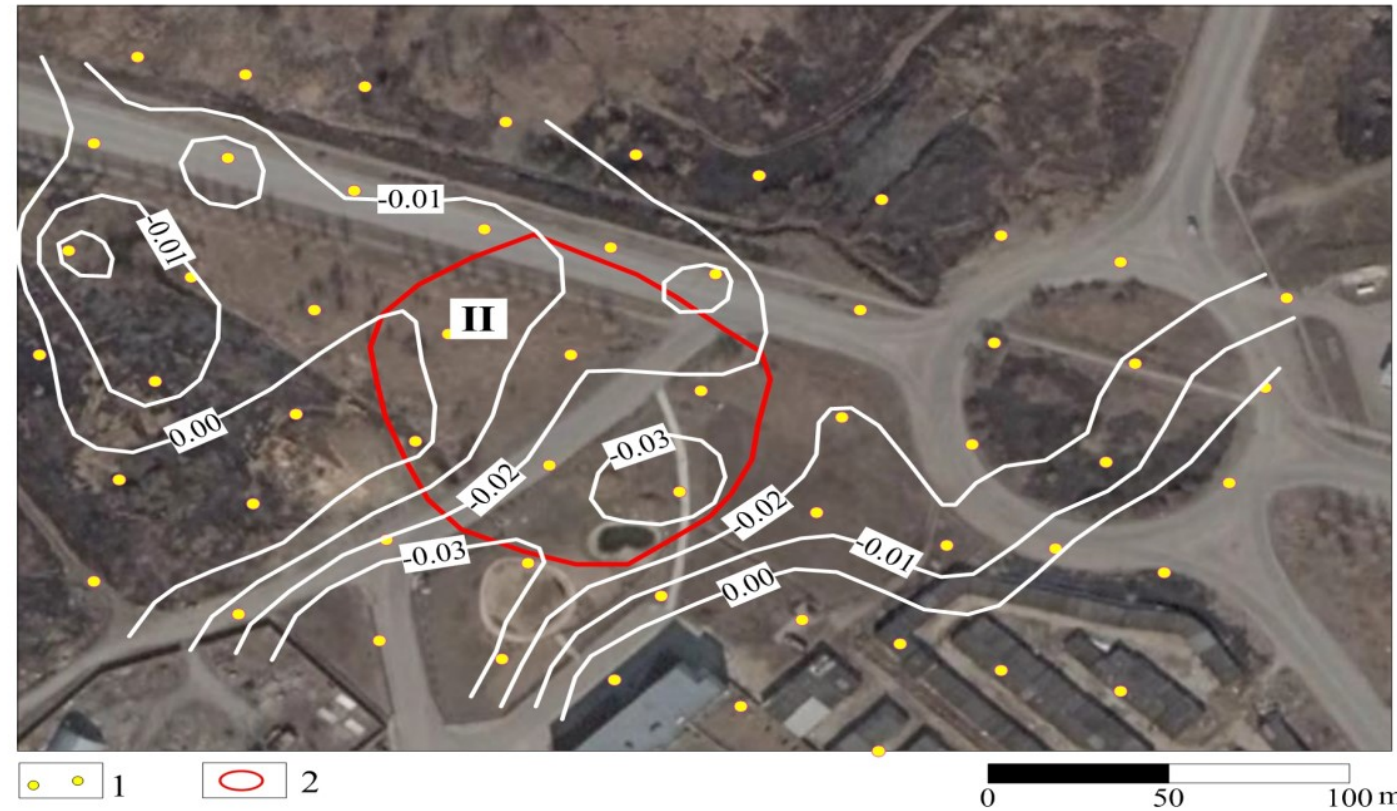

Рис. 7. Динамическая аномалия силь тяжести сентябрь - февраль 2011 г2. на фоне городской застройки: 1 - гравиметрические пункты, 2 - контур провала в декабре 2011 г.

на рис. 5 и $6, a)$ в пределах обнаруженной зоны отрицательных локальных аномалий гравитационного поля северного простирания и динамической аномалии силы тяжести, выявленной по съемке в сентябре 2011 г. К 2014 году на месте этих провалов сформировалось техногенное озеро, простирание которого определилось локальной отрицательной аномалией силы тяжести, показанной на рис. 5.

В 2016-2018 гг. гравиметрические работы продолжались в восточной части данной площади (рис. 8,9). За период с сентября по декабрь 2016 г. здесь зафиксирована динамическая аномалия гравитационного поля амплитудой 0,022 мГал (более чем в три раза превышающая точность съемки), размерами $250 \times 125 \mathrm{M}$. Результаты интерпретации показали, что уменьшение поля на 0,02 мГал при данной форме и размере выделенной динамической аномалии может быть обусловлено источником поля, находящимся на глубине 20-50 м (рис. 8,б), плотность которого

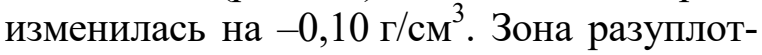
нения находится в верхней части водозащитной толщи. Через год, к сентябрю 2017 г., в пределах данной динамической аномалии произошли оседания земной поверхности на 15-20 см (рис. 8,a).

В ноябре 2018 г. эпицентр динамической аномалии сместился на юг площа-
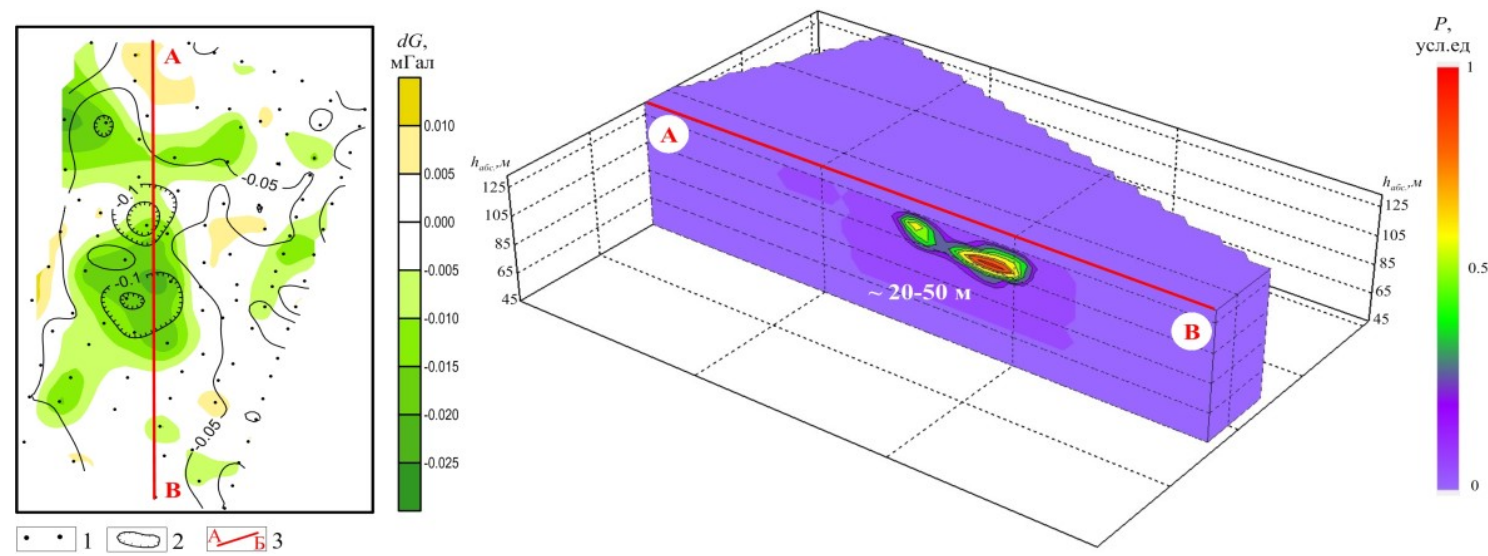

Рис. 8. Динамическая аномалия силы тяжести (сентябрь - декабрь 2016 г.) и оседания земной поверхности к сентябрю 2017 г (а). Результат решения обратной задачи динамической аномалии (б) 
ди (рис. 9,a). Амплитуда аномалии достигла $-0,06$ мГал. При этом глубина источника аномалий в центральной части участка осталась прежней 20-50 м, а на юге увеличилась до 80 м (рис. 9,б). Зона разуплотнения, создающая данную динамическую аномалию, представляет, на наш взгляд, повышенную опасность, учитывая, что она также находится в пределах локальной отрицательной аномалии силы тяжести, т.е. в зоне предполагаемого природного разуплотнения пород. Дальнейшие гравиметрические наблюдения позволят проконтролировать динамику процессов, происходящих в недрах. вающих предприятий, предупреждению событий, связанных с геологическими особенностями территории или с разработкой месторождения, которые могут спровоцировать начало необратимых для сохранения рудника изменений состояния вышезалегающих водозащитных толщ. Применять разработанную в рамках проекта методологию возможно всем горнодобывающим предприятиям с шахтным способом добычи сырья, в частности на рудниках Верхнекамского месторождения калийных солей в Пермском крае, где проблема сохранности водозащитной толщи стоит особенно остро. Социально-
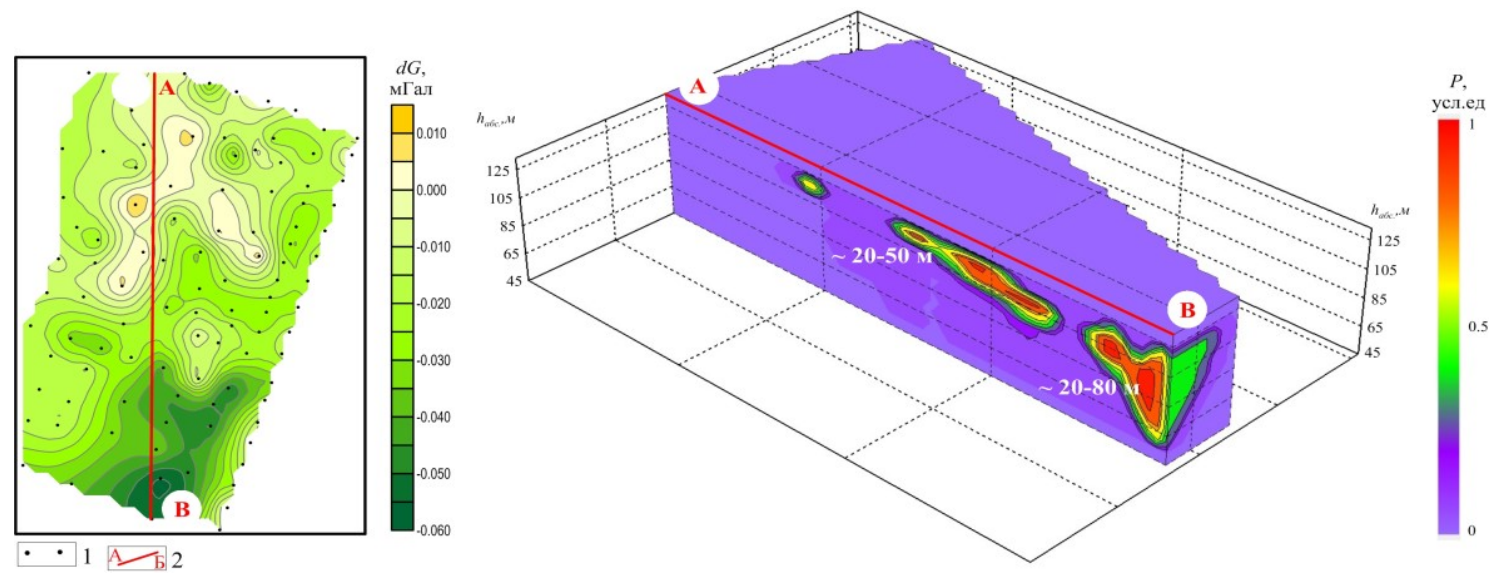

Рис. 9. Динамическая аномалия силь тяжести (сентябрь 2017 - ноябрь 2018) (а).

Результат решения обратной задачи динамической аномалии (б)

\section{Заключение}

Результаты выполнения работ по региональному проекту РФФИ способствуют безаварийной работе горнодобы- экономический эффект от использования технологии, созданной на основе результатов данного исследования, заключается прежде всего в повышении производственной и экологической безопасности.

\section{Библиографический список}

1. Абрамов Д.В., Бычков С.Г. Возможная природа пульсаций гравитационного поля // Вопросы теории и практики геологической интерпретации геофизических полей: материалы 45-й сессии Междунар. семинара им. Д.Г.Успенского. - Казань: Казанский ун-т, 2018. - С. 16-18.

2. Бычков С.Г. Аномальные временные ряды записи гравиметров // Стратегия и процессы освоения георесурсов. Сб. науч. тр. Вып. 16. - Пермь: ГИУрОРАН, 2018. - С 140-142.

3. Бычков С.Г. Гравиметрический мониторинг: возможности, задачи, перспективы // Стратегия и процессы освоения георесурсов. Сб. науч. тр. Вып. 15. - Пермь: ГИ УрО РАН, 2017, С. 146-149.

4. Бычков С.Г., Долгаль А.С., Костицын В.И., Симанов А.А., Хохлова В.В. Редуцирование высокоточных гравиметрических наблюдений // Геодезия, картография, кадастр, ГИС - проблемы и перспективы развития: тез. докл. Междунар. науч.-техн. конф. (РБ, Новополоцк, 9-10.06.2016 г.) / Полоцкий гос. ун-т. - Новополоцк: ПГУ, 2016. - С. 26-30.

5. Бычков С.Г., Долгаль А.С., Симанов А.А., Хохлова В.В. Опыт использования современных процедур обработки высокоточных гравиметрических съемок // Интерэкспо ГЕО-Сибирь-2017. XIII Междунар. науч. конгр. (17-21 апреля 2017 г.). Междунар. науч. конф. «Недропользование. Горное дело. Направления и технологии поиска, разведки и разработки месторождений полезных ископаемых. Экономика. Геоэкология». - Т. 3. - Новосибирск: СГУГиТ, 2017. - С. 99-104. 
6. Бычков С.Г., Мичурин А.В., Симанов А.А. Гравиметрический мониторинг аварийных участков рудников Верхнекамского месторождения калийных солей // Материалы 44-й сессии Междунар. науч. семинара им. Д.Г.Успенского «Вопросы теории и практики геологической интерпретации геофизических полей» (г. Москва, 23-27.01.2017 г.) - М.: ИФЗ РАН, 2017. - С. 75-79.

7. Бычков С.Г., Мичурин А.В., Симанов А.А. Гравиметрический мониторинг аварийных участков рудников Верхнекамского месторождения калийных солей // Геология и полезные ископаемые Западного Урала: сб. статей по материалам Всерос. науч.-практ. конф. с междунар. участием. Пермь: ПГНИУ, 2017. - С. 132-137.

8. Бычков С.Г., Мичурин А.В., Симанов А.А. Гравиметрический мониторинг карстовых процессов // Глубинное строение, геодинамика, тепловое поле Земли, интерпретация геофизических полей: Девятые научные чтения памяти Ю.П. Булашевича (18-22.09.2017). - Екатеринбург, ИГфУрО РАН, 2017 - C. 93-97.

9. Бычков С.Г., Мичурин А.В., Симанов А.А. Гравиметрический мониторинг рудников Верхнекамского месторождения калийных солей // Геофизика, - 2017. - №5. - С. 10-16.

10. Бычков С.Г., Мичурин А.В., Симанов А.А. Результаты гравиметрического мониторинга аварийных участков рудников Верхнекамского месторождения калийных солей // Вопросы теории и практики геологической интерпретации геофизических полей: материалы 45-й сессии Междунар. семинара им. Д.Г.Успенского. - Казань: Казанский ун-т. - 2018. - С. 130-131.

11. Бычков С.Г., Простолупов Г.В., Симанов А.А., Щербинина Г.П. Гравиметрические исследования аварийных участков рудников Верхнекамского месторождения калийных солей // Геология и полезные ископаемые Западного Урала: сб. ст. юбилейной конф., посвящ. 100-летию Перм. ун-та и 85-летию геол.ф-та. - Пермь: ПГНИУ, 2016. - С. 124-127.

12. Бычков С.Г., Простолупов Г.В., Щербинина Г.П. Наземно-подземная гравиразведка на Верхнекамском месторождении калийных солей // Теория и практика разведочной и промысловой геофизики: материалы Междунар. Науч.-практ. конф. - Пермь, 2016. - С. 76-80.

13. Бычков С.Г., Простолупов Г.В., Щербинина Г.П. Прикладные задачи гравиметрии при обеспечении безопасности отработки месторождения растворимых солей // Геофизика, 2018. - №5. - С. 4-12.

14. Бычков С.Г., Простолупов Г.В., Щербинина Г.П. Применение наземно-подземной гравиразведки на Верхнекамском месторождении калийных солей // Геофизика, - 2016. - №5. - С. 37-41.

15. Бычков С.Г., Симанов А.А. Возможная природа повышенной дисперсии отсчетов гравиметра // Геология и полезные ископаемые Западного Урала. - Вып. 1(38). - Пермь: ПГНИУ, - 2018. - С. 163-167.

16. Мичурин А.B. Комплексная интерпретация геофизических данных при поисках медно-порфирового оруденения // Стратегия и процессы освоения георесурсов. - Вып. 16. - Пермь: ГИ УрО РАН, 2018. C. $150-152$.

17. Мичурин A.B. Решение линейной обратной задачи гравиразведки по площадным измерениям методом минимизации эмпирического риска // Стратегия и процессы освоения георесурсов. Сб. научн. трудов, - Вып. 14. - Пермь: ГИ УрО РАН, 2016. - С. 147-149.

18. Простолупов Г.В. Определение количественных параметров источников поля силы тяжести методом «Полюс» // Стратегия и процессы освоения георесурсов. Сб. научн. трудов, - Вып. 14. Пермь: ГИ УрО РАН, 2016. - С. 150-156.

19. Простолупов Г.В. Оптимальные параметры реализации метода Polus $2 \mathrm{~d}$ при решении обратной задачи гравиметрии // Стратегия и процессы освоения георесурсов. - Вып. 16. - Пермь: ГИ УрО PAH, 2018. - С. 156-160.

20. Простолупов Г.В. Свойства локализации полюсов потенциала силы тяжести относительно источников поля и практическая реализация метода POLUS // Вопросы теории и практики геологической интерпретации геофизических полей: материалы 45-й сессии Междунар. семинара им. Д.Г.Успенского. - Казань: Казанский ун-т, 2018. - С. 70-71.

21. Симанов А.А. Гравиметрический мониторинг карстово-суффозионных процессов в районах интенсивного освоения недр // Стратегия и процессы освоения георесурсов. - Вып. 16. - Пермь: ГИ УpO PAH, 2018. - C. 161-163.

22. Симанов A.A. Опытные геофизические работы на территории историко-природного комплекса «Ледяная гора и Кунгурская ледяная пещера» // Стратегия и процессы освоения георесурсов: сб. науч. тр. - Вып. 14. - Пермь: ГИ УрО РАН, 2016. - С. 160-162.

23. Хохлова В.В. Вычисление гравитационных эффектов в сферической системе координат // Стратегия и процессы освоения георесурсов. Сб. науч. тр. - Вып. 14. - Пермь: ГИ УрО РАН, 2016. - С. 166-168.

24. Щербинина Г.П., Простолупов Г.В. Геологическое строение области сочленения ВосточноЕвропейской Платформы и Соликамской депрессии Предуральского прогиба в южной части Верхнекамского месторождения калийных солей // Вопросы теории и практики геологической интерпретации геофизических полей: материалы 45-й сессии Междунар. семинара им. Д.Г.Успенского. - Казань: Казанский ун-т. 2018. - С. 115. 
25. Щербинина Г.П., Простолупов Г.В. Тектоника области сочленения Восточноевропейской платформы и Соликамской депрессии Предуральского прогиба // Вестник Пермского университета. Геология. - 2018. - №3. - С. 200-207.

26. Bychkov S. The tomographic transform of the gravity field and their geological interpretation // 8th Saint Petersburg International Conference \& Exhibition «Saint Petersburg 2018. Innovations in Geosciences Time for Breakthrough» - Saint Petersburg, Russia (9-12 April 2018). Submission ID: 44418. 6 p.

27. Bychkov S., Michurin A., Simanov A. Interpretation of results gravity monitoring of karst processes // 8th Saint Petersburg International Conference \& Exhibition «Saint Petersburg 2018. Innovations in Geosciences - Time for Breakthrough»-Saint Petersburg, Russia (9-12 April 2018). Submission ID: 44417. 6 p.

28. Bychkov S.G., Michurin A.V., Simanov A.A. Gravimetric monitoring of technogenic impact on geological environment // Engineering and Mining Geophysics 2018 (23-27 April 2018), - Almaty, Kazakhstan. Submission ID: 46144.6 p.

\title{
METHODOLOGY OF STUDYING DECOMPRESSION ZONES IN THE WATERPROOF STRATUM OF POTASSIUM SALTS BY GROUND AND GROUND-UNDERGROUND GRAVIMETRY
}

\author{
S.G. Bychkov, A.V. Michurin, G.V. Prostolupov, A.A. Simanov, V.V. Khokhlova
}

\section{Mining Institute UB RAS}

Research on the use of gravity data was carried out (supported by regional 2016-2018 contest RFBR) to predict negative engineering and geological phenomena caused by the process of potassium salt deposits exploitation. In the course of the project, techniques of high-precision ground-based, ground-underground gravimetric surveys and monitoring observations were developed, the adaptation of methods for processing gravimetric data of these surveys was performed methods for processing the gravimetric data of these surveys were adapted, computer-based algorithms for processing and interpreting observations were developed. Ways of interpreting dynamic anomalies, as well as ground and ground-underground gravimetric surveys based on the use of qualitative and quantitative methods for extracting geological information from gravimetric data, are proposed. Gravimetric monitoring in emergency areas of the mines of the Verkhnekamskoye potassium salt deposit has shown its high efficiency. It has been established that the dips of the earth surface and areas of increased subsidence caused by the flooding of the mines are clearly recorded in the gravitational field. By combining negative local gravity anomalies, which are interpreted as natural weakened zones, with negative dynamic anomalies associated with the decompression processes, hazardous geological processes can be successfully predicted.

Keywords: gravimetry, salts, mine, gravity anomaly, three-dimensional model.

\section{Сведения об авторах}

Бычков Сергей Габриэльевич, доктор геолого-минералогических наук, заведующий лабораторией геопотенциальных полей, Горный институт УрО РАН - филиал Пермского федерального исследовательского центра УрО РАН (ГИ УрО РАН), 614007, г. Пермь, ул. Сибирская, 78А; e-mail: bsg@mi-perm.ru

Мичурин Антон Владимирович, кандидат технических наук, научный сотрудник, ГИ УрО РАН; e-mail: ami.perm@mail.ru

Простолупов Геннадий Валерьевич, кандидат технических наук, старший научный сотрудник, ГИ УpO PAH; e-mail: gravik2@rambler.ru

Симанов Алексей Аркадьевич, кандидат технических наук, научный сотрудник, ГИ УрО РАН; e-mail: simanov@mi-perm.ru

Хохлова Валерия Васильевна, младший научный сотрудник, ГИ УрО РАН; e-mail: valxov@gmail.com 